\title{
Adolescent's motivation and their perceptions of learning contexts of foreign language
}

\section{Motivação de adolescentes e suas percepções do contexto de aprendizagem em língua estrangeira}

\author{
Ana Raquel Abelha CAVENAGHI' \\ José Aloyseo BZUNECK \\ Sueli Édi RUFINI ${ }^{2}$
}

\begin{abstract}
The aim of the present study was to investigate motivational orientations of 396 adolescents of public schools and their perceptions of their learning contexts. About half of the sample suited English as a compulsory language, while others studied Spanish as an elected language. Data were collected through a Likert-type self report questionnaire with questions related to mastery and work avoidance achievement goals, to perceptions of interesting classes and utility value. Results showed significant positive relations among mastery goal orientation and perceptions of interesting classes and utility, and negative relations among work avoidance goal orientation and those variables. Regression analyses showed that perceptions of interesting classes and utility value predict mastery goal orientation. Some significant differences aroused among students of the two learning contexts. Results were discussed in the light of motivational theories and some suggestions for new researches and for educational practices as well with adolescents were drawn.
\end{abstract}

Uniterms: Achievement goals; Foreign language; Interest; Motivation.

\section{Resumo}

O estudo investigou as orientações motivacionais de 396 adolescentes e suas percepções do contexto de aprendizagem de uma língua. Parte dos alunos estudava espanhol por escolha própria e, para os demais, o inglês era obrigatório. Como instrumento, utilizou-se um questionário em escala Likert com questões sobre as metas de realização "aprender" e "evitação do trabalho", percepção de aula interessante e o valor de utilidade dessa aprendizagem. Diferenças significativas foram encontradas entre os alunos das duas línguas estrangeiras. Apareceram relações positivas significativas entre a meta de realização "aprender" e a percepção de aula interessante e o valor de utilidade, e relações negativas entre a meta "evitação do trabalho" e essas mesmas variáveis. Pela análise de regressão, percepções de aula interessante e de utilidade predizem a meta de realização aprender. Os resultados foram discutidos à luz das teorias motivacionais e foram extraídas algumas sugestões tanto para novas pesquisas como para práticas educacionais com adolescentes.

Unitermos: Metas de realização; Língua estrangeira; Interesse; Motivação.

\section{$\nabla \nabla \nabla$}

1 Universidade Estadual de Londrina, Centro de Letras e Ciências Humanas, Curso de Letras Espanhol, Departamento de Letras Estrangeiras Modernas. Campus Universitário, Rod. Celso Garcia Cid Pr 445, km 380, 86051-990, Londrina, PR, Brasil. Correspondência para/Correspondence to: A.R.A. CAVENAGHI. E-mail: <anaracavenaghi@hotmail.com>.

2 Universidade Estadual de Londrina, Centro de Educação, Comunicação e Artes, Departamento de Educação. Londrina, PR, Brasil. Article developed as part the dissertation of the A.R.A. CAVENAGHI, intitled "A motivação de adolescentes para aprendizagem de língua estrangeira e suas percepções do contexto de sala de aula". Universidade Estadual de Londrina, 2010. 
Many researchers attest general decline in student motivation as they advance in school grades (Kaplan \& Maehr, 2002; Zusho \& Pintrich, 2001). There are several factors responsible for this negative scenario, among which, as pointed by Roeser and Galloway (2002) regarding adolescents, are the new interests of social nature that involve them. On the other hand, adolescents themselves report that classes are uninteresting, subjects are complex and without personal relevance, resulting in a certain devaluation of learning and consequent demotivation (Vallerand, Fortier \& Guay, 1997; Wigfield \& Eccles, 2000).

In the case of foreign language learning, Dörnyei (2003) highlights its particularities, among which the factor that its learning presupposes knowledge of elements of the communication code, which are grammar and lexical items, besides social and cultural aspects from the target language community. Moreover, Oxford and Shearin (1994) suggest that learning another language is considered a difficult process and, before that, motivation will be a key determinant of success. Thus, having knowledge of academic motivation and student perception regarding the social context of the classroom is essential for teachers to adopt appropriate interventions to promote an environment focused on the motivation to learn.

Early researchers on motivation to learn a foreign language, such as Gardner and Lambert (1959), were based on the socio-educational model, according to which motivation is linked to the desire of the learner to interact with the target language group (integrative orientation) and the pursuit of practical benefits from this learning (instrumental orientation). In the 90s, researchers as Clément, Dörnyei and Noels (1994) and Oxford and Shearin (1994) considered this theoretical model limited, suggesting the adoption of other approaches to the processes involved in motivation to learn a foreign language, which actually happened. For example, the theory of self-determination was the reference of the studies of Noels, Pelletier and Clément (1999), Noels, Pelletier, Clément and Vallerand (2000) and Tsai, Kunter, Ludtke, Trautwein and Ryan (2008), which included the variable Interest. In another strand, Liem, Lau and Nie (2008) have supported the theory of value-expectancy and achievement goal theory and Williams, Burden and Al-Baharna (2002) adopted the theory of causal attributions. This variety of approaches reflects the complexity of motivation in the school context as an object of study.

Literature has shown that student motivation is multifaceted and results from many factors, considered in several theoretical approaches (Bzuneck, 2009a). Among them, the achievement goal theory has been widely used as a reference for scholars concerned with the practices in the classroom. As a social-cognitive approach, it emphasizes both cognitive variables, including the focus on a target, such as environmental factors in the explanation of the motivation to learn. According to its proponents, student motivation is influenced by their orientation to a type of goal achievement, understood as the reason or purpose in performing tasks and in the application of effort, influencing the quality of their involvement (Bzuneck, 2009b; Kaplan \& Maehr, 2002; Liem et al., 2008; Urdan \& Midgley, 2003; Urdan \& Schoenfelder, 2006; Zusho \& Pintrich, 2001).

Four different achievement goals have been included in the studies. The first one is learning achievement goal by which the student seeks to develop competence and researches have revealed that this goal is associated with interest, preference for challenge, persistence and better performance. Another goal is called performance, when there is concern either to demonstrate ability (performance-approach) or to avoid the demonstration of lack of competence and unfavorable judgments (performance-avoidance). Finally, with work avoidance goal the student aims to succeed in learning, provided that they do not have to apply effort, which, if required, should be at a minimum level.

Research results confirmed the assumptions of the theory that the classroom environment, as perceived by the students, is a crucial factor in the development of different achievement goals (Ames, 1992; Bzuneck, 2009b). Guimarães (2009) described some teaching methods that have the potential to promote learning achievement goal, the most educationally desirable motivation for its effects on students'engagement. Among such strategies, we will explore here the ones related to the way tasks are assigned and the promotion of learning autonomy. 
In order to implement learning achievement goal orientation, we highlight strategies to demonstrate the significance and value of academic activities, in addition to challenges given in the proper level. Specific literature has also reported the positive effects of using Embellishments so as to promote students' interest in learning, so called situational interest. Motivational embellishments using music, games, fantasy, drama, among others, belong to this category (Ames, 1992; Bzuneck, 2010; Tsai et al., 2008).

Supporting students' autonomy (Ames, 1992; Guimarães, 2009) basically means to allow them freedom to make choices and give them responsibility and to open to participation in decisions related to their learning. Several studies have demonstrated the effectiveness of this strategy for engaging them in learning activities (Patrick, Skinner \& Connell, 1993; Reeve \& Jang, 2006).

Studies on the academic motivation in the light of the Achievement Goal Theory have raised questions concerning the motivation for foreign language learning in school. What is the quality of motivation for Brazilian adolescents in terms of achievement goals to learn a foreign language? And what is the relationship of this motivation with social-contextual variables of the classroom? Discovering answers to these questions was the overall goal of this research. More specifically, the aims of this study were: (1) to assess adolescent students' motivation in two foreign language learning contexts, regarding their adoption of a learning or a work avoidance achievement goal; (2) to evaluate students' perceptions of the classroom teaching in the promotion of situational interest and the use of motivational embellishments by teachers; (3) to assess whether, and to what extent, students perceive utility value in the study of a foreign language in school; and (4) to analyze relationships among perceptions of the classroom teaching and both learning and work avoidance achievement goals orientations.

\section{Method}

\section{Participants}

The total sample of 396 Brazilian adolescents (227 girls and 169 boys), aged 12 to 17 years, was formed by two groups. Students $(n=244)$ in $7^{\text {th }}$ and $8^{\text {th }}$ grades of Basic Education and from the three grades of High School of Paraná State schools composed the first group. All those students were studying English as a mandatory curricular subject, with no option for another language. The second group $(n=152)$ consisted of students studying Spanish by their own choice, also in state schools, in a space called Centro de Línguas Estrangeiras Modernas (CELEM, Center of Modern Foreign Languages).

\section{Instruments}

A pencil and paper questionnaire initially asked students' demographic information, followed by three scales designed to assess, respectively, students' achievement goals, their perception of classroom teaching and, finally, their perception of utility value of the foreign language. Items were anchored on a 5-point Likert-type scale ranging from 1, strongly disagree to 5 totally agree. The questionnaire items were based on existing national and international instruments, but with some adaptations required by the goals of this study. A pilot study was carried out with students who were not included in the main sample. Following this procedure the wording of some items was improved, allowing its full understanding by the students (Appendix).

Achievement Goals Scale: comprised 16 statements designated to verify adolescents' motivational orientation. The scale was subjected to a principal component analysis followed by a Varimax rotation, from which two factors emerged. Eight items related to Factor 1 , with an internal consistency index of 0.86 by Cronbach's $\alpha$, identified as Learning Achievement Goal Orientation. Remaining eight items loaded on Factor 2, with $\alpha=0.73$, identified as Work Avoidance Goal Orientation.

Perceptions of an Interesting Classroom Teaching: Although scale's ten items were created to assess a general perception of a teaching as promoting situational interest, principal components analysis found two distinct factors. Factor 1 gathered six items with $\alpha=0.86$ and It was called Perception of Interesting Classroom Teaching. To Factor 2 converged four items, with $\alpha=0.82$, which is now called Perception of Motivational Embellishments. 
Perceptions of Utility Value of Foreign Language: Out of the ten items constructed, five formed Factor 1, with $\alpha=0.77$, meaning devaluation or perceived of uselessness of the foreign language. Another five items formed Factor 2, related to the positive perception of utility value, with $\alpha=0.56$.

\section{Procedures}

The first author conducted data collection in all classes, during the class time previously scheduled. For this, written permission was requested from the direction of the selected schools, parents'authorizations for their children to participate in the study, besides the declaration of the free will of the students to participate. There were no refusals to participate. For the questionnaire application, the requirements of Resolution no 196/96 of the National Health Council were observed, with the approval of the University Ethics in Research Committee.

\section{Results}

Data were submitted to statistical analyses using Statistica 7 program. Initially, as descriptive statistics, we will present the mean scores and standard deviations on the variables Achievement Goals, Perceptions of Interesting Classroom Teaching and of the Utility Value by comparing students in both contexts of English as a compulsory language $(n=244)$ and Spanish as an option $(n=152)$.

As can be seen in Table 1, the mean scores of the two groups of students in Learning Goal Orientation, Perception of Interesting Classroom Teaching and in the
Utility Value of that language learning were relatively high. However, when learners were discriminated by the condition of compulsory or of free choice of language, significant differences emerged. That is, students of Spanish as an elective subject, when compared with the students of English as compulsory language, showed significantly higher scores on the learning goal orientation, on the perceptions of interesting classroom teaching, and on the use of embellishiment. Conversely, these same students'scores on work avoidance goal were significantly lower than their English language classmates'.

A Pearson product-moment correlation analysis between the scores on the three different variables, now considered the total sample $(n=396)$, was conducted. The correlation values, all statistically significant, appear in Table 2. Firstly, in accordance with the achievement goal theory, the correlation was negative between the scores on contrasting goals-learning versus work avoidance. The relationship between the learning goal orientation and judgment of uselessness of the foreign language was also negative. On the other hand, learning goal was positively related to perception of interesting classroom teaching, use of embellishments, and utility of the foreign language. The avoidance goal, in turn, appeared negatively related to perception of interesting classroom teaching, use of embellishments, and, in a lesser degree, to the judgment of foreign language's uselessness, but its relation with perception of utility was positive.

In addition to correlations, a regression analysis was applied to verify if perceptions of Interesting classroom teaching, use of embellishments and judgments about foreign language's uselessness or

Table 1

Means and Standard Deviations of the goals orientations, and all perceptions, with students discriminated English and Spanish classroom contexts in public schools of Londrina (2010)

\begin{tabular}{|c|c|c|c|c|c|c|}
\hline \multirow{2}{*}{ Variables } & \multicolumn{2}{|c|}{ English $(n=244)$} & \multicolumn{2}{|c|}{ Spanish $(n=152)$} & \multirow{2}{*}{$t$} & \multirow{2}{*}{$p$} \\
\hline & M & SD & M & SD & & \\
\hline Learning achievement goal & 3.23 & 0.97 & 3.75 & 0.71 & 5.72 & 0.001 \\
\hline Work avoidance goal & 2.79 & 0.84 & 2.44 & 0.65 & 4.39 & 0.001 \\
\hline Interesting class teaching & 3.46 & 1.06 & 4.23 & 0.74 & 7.85 & 0.001 \\
\hline Embellishments & 2.10 & 0.76 & 3.32 & 0.89 & 14.56 & 0.027 \\
\hline Perception of uselessness & 1.91 & 0.95 & 1.50 & 0.62 & 4.74 & 0.001 \\
\hline Utility value & 3.96 & 0.71 & 3.93 & 0.65 & 0.32 & 0.20 \\
\hline
\end{tabular}


Table 2

Pearson correlations among the measures, considering the total sample $(\mathrm{N}=396)$ with English and Spanish language students from public schools of Londrina (2010)

\begin{tabular}{|c|c|c|c|c|c|c|}
\hline & $\begin{array}{l}\text { Learning } \\
\text { goal }\end{array}$ & $\begin{array}{c}\text { Work } \\
\text { avoidance }\end{array}$ & $\begin{array}{c}\text { Interesting class } \\
\text { teaching }\end{array}$ & Embellishments & $\begin{array}{c}\text { Perception of } \\
\text { uselessness }\end{array}$ & $\begin{array}{l}\text { Utility } \\
\text { value }\end{array}$ \\
\hline Learning goal & & -0.60 & 0.67 & 0.46 & -0.52 & 0.43 \\
\hline Work avoidance & & & -0.55 & -0.31 & 0.53 & -0.22 \\
\hline Interesting classroom & & & & 0.58 & -0.62 & 0.25 \\
\hline Embellishment & & & & & -0.29 & 0.22 \\
\hline Perception of uselessness & & & & & & -0.30 \\
\hline Utility value & & & & & & \\
\hline
\end{tabular}

Note: All correlation values are significant $(p=0.001)$.

Table 3

Regression Analyses with English and Spanish language students from public schools of Londrina (2010)

\begin{tabular}{|c|c|c|c|c|c|c|}
\hline \multirow{2}{*}{ Independent variables } & \multicolumn{3}{|c|}{ Goal learning } & \multicolumn{3}{|c|}{ Goal work avoidance } \\
\hline & Beta & $t$ & $p$ & Beta & $t$ & $p$ \\
\hline Interesting classroom & 0.47 & 9.08 & 0.00 & -0.34 & -5.70 & 0.01 \\
\hline Embellishments & 0.09 & 2.25 & 0.02 & -0.01 & -0.32 & 0.74 \\
\hline Perception of uselessness & -0.12 & -2.76 & 0.00 & 0.30 & 5.85 & 0.01 \\
\hline Utility value & 0.25 & 6.97 & 0.00 & -0.03 & -0.84 & 0.39 \\
\hline
\end{tabular}

Note: $t$ : Student's $t$-test; $p$ : significance probability.

utility have predictive value in relation to motivational orientations, identified as learning goal and work avoidance goal. Results in Table 3 show that the perception of interesting classroom teaching proved to have a positive and significant predictive value to learning goal, with $47 \%$ of the total variance of this result are due to the relationships between the two variables and it is not due to other factors. Likewise, learning goal was predicted by perception of foreign language's utility.

Concerning work avoidance goal, regression analysis showed that perception of interesting classroom teaching, use of embellishments and utility perception were negative predictors of that goal. In contrast, the perception of uselessness of the language was the only positive predictor of work avoidance goal, explaining $30 \%$ of the total variability.

\section{Discussion}

In the present study we aimed at to investigate Brazilian teenagers' motivational orientations to learn a foreign language and its relationships with the social environment in the teaching of this subject. Significant statistical relationships were discovered, which will be explained in the light of the Achievement Goal Theory, the theoretical framework adopted in this study.

The first objective was to discover the extent and quality of student motivation related to the purposes or reasons for involvement in the study of foreign languages. The results revealed throughout the sample a prevalence of the learning goal orientation, which equates to a quality of motivation that allows, according to the theory (Ames, 1992; Bzuneck, 2009a; Urdan \& Schoenfelder, 2006), the expectation of appreciable engagement in learning activities. On the other hand, the entire sample also had an orientation, although to a lesser degree, to work avoidance goal, which means poor motivation, characterized by the intention to apply the minimum possible effort. Thus, the data for the two subscales of goals will be discussed together.

Considering the higher mean scores of the learning goal items, we cannot rule out, to some extent, a trend of many students to meet social expectations, 
that is, even if unconsciously, they may have marked points on the scale that did not correspond to their truth, but that would ensure them a more positive image. Holtgraves (2004), among others, demonstrates how this bias can easily occur and thus it contaminates the veracity of self-report. This observation, according to the author, implies the need for greater care in the elaboration of measurement scales in the case of constructs such as this.

In the present study, one can still assume that the higher scores tendency in-learning goal was facilitated by content of questions that represent an educationally desirable goal, which is to pursue their knowledge and skills improvement. However, when the items dealt with the possibility of success without effort, typical of work avoidance goal, there was also a certain degree of agreement in the responses. But the negative correlation found between the two measures of achievement goals means that, in the whole sample, higher scores on one of them were accompanied by lower scores in the other and vice versa. In summary, one cannot conclude by a contradiction in the answers, but data suggests that in such motivation measurement it is not enough to use learning goals items only, but here is need to assess the possible adoption of work avoidance as well.

According to the goal theory, the orientation to learning achievement goal is associated with the value of learning. Furthermore, a different approach, according to the expectation-value theory (Durik, Vida \&Eccles, 2006; Eccles \&Wigfield, 2002) one of the critical motivational factors is precisely for the student to realize that learning is important, for example, because it is helpful in their lives. This was found with this sample. All students, regardless of the foreign language, demonstrated to value it, that is, to find their learning important, even with mean scores higher than in all the other variables considered. The correlation between value perception and learning goal measures was positive, a fact that was also found by Liem et al. (2008). And, in accordance with the assumptions of the theory (Ames, 1992; Bzuneck, 2009b), the regression analysis on the present data found that the perceived utility value positively predicts learning goal and, negatively, avoidance goal. Consistent with this finding, the group

350 scores of perception of worthlessness or devaluation of the foreign language appeared as negatively correlated with the other measures, with one exception, the avoidance goal, with which it correlated positively.

It was not assessed here the degree to which teachers directly contributed for valuing the foreign language. However, its valuation by the groups can be explained, at least in part, by the cultural atmosphere that pervades English language for its utility, for example, in the computing area, business relationships and the world of entertainment and music, while Spanish appears as the foreign language of the moment, given our proximity to countries where it is spoken.

An important objective of this study was to investigate whether there are significant differences, in several variables, between students of English and Spanish. Firstly, regarding to achievement goals, significant differences were found between the two groups of students. Mean scores were significantly higher in the learning goal among students of Spanish and, conversely, the mean scores in the avoidance goal were higher among students of English.

One explanation for the superiority of the students of Spanish can be related to the fact that, in schools where this language is studied, students were provided with possibility of choice, unlike the case of English, a compulsory language in the curriculum. It would also explain why English students are more oriented to work avoidance goal than those studying Spanish. Teaching that offers the students the possibility to choose, which corresponds to an aspect of the exercise of autonomy, has been associated with the orientation to learning goal (Ames, 1992; Guimarães, 2009). In addition, according to Self-Determination Theory, autonomy support is crucial to intrinsic motivation and to the self-regulated forms of extrinsic motivation (Reeve, 2004). Notwithstanding, we cannot discard the influence of other factors in the explanation of the qualitatively higher motivation for the students learning Spanish, among them the fact that this language is so similar to ours and that it is spoken in countries closer to us.

However, different mean scores were also found in the measures of perceptions of interesting classroom and use of embellishments in teaching each language. The question is about social and environmental 
variables related to teachers' actions, but assessed as perceived by students, a requirement recommended in specific literature (Urdan \& Midgley, 2003; Zusho \& Pintrich, 2001). Though different by factor analysis, interesting class perception and use of embellishments can be considered as variables that belong to a single comprehensive construct, which would be the situational interest, a case in which interest is prompted by environmental stimuli (Hidi, 2001; Hidi \& Harackiewicz, 2000; Tsai et al., 2008). Situational interest is distinguished from personal interest, which is derived from internal and not environmental sources, and that was not an object of measurement herein. By their nature, motivational embellishments are designed to make the class attractive, so much so that the correlation between the measures of perceived interesting class and use of embellishments were positive, in a similar way as it has been described in literature (Ames, 1992; Cordova \& Lepper, 1996; Parker \& Lepper, 1992).

Once again, in comparison with the English language students, the students of Spanish showed higher scores on these two measures, that is, their teachers are more perceived as promoters of interest in class. Moreover, perception of interesting class and embellishments were found to have a positive predictive value to learning goal and negative predictive value to the work avoidance goal. Positive and significant correlations were also found between scores in each of these two perceptions and the perception of utility value of the language. However, as this is a correlation, one cannot infer a causal effect. On the other hand, the data is consistent with the postulates of achievement goal theory (Ames, 1992; Bzuneck, 2009b; Dowson \& Mclnerney, 2001). The orientation of the Learning goal, the only one desirable, is associated with situational interest, and, the work avoidance goal, as predicted, characterized by reduced engagement, was associated to the perception of uninteresting classroom teaching. In short, the quality of the motivation for foreign language, measured by the orientation to achievement goals, appeared in this study associated with teaching methods as perceived by students. This result provides valuable suggestions for language teachers and teachers in general. Teachers should bear in mind the complaint of teenagers about uninteresting lessons, boring content stripped of personal meaning (Vallerand et al., 1997; Wigfield \& Eccles, 2000).
Some limitations, however, must be pointed out in this research. Firstly, we did not evaluate the actual performance of students in each language, which could possibly be associated with motivational measures. Moreover, in the comparisons between groups of students we did not consider variables such as the number of students in class, a weekly schedule of the subject and type of available support material. Lastly, we did not compare students' motivational variables in relation to their school grade or according to gender. Therefore, suggestions for further studies to advance the understanding of motivation for learning a foreign language in school, especially with teenagers can be made. It is unveiled, in this area and in our country, a vast space to be explored, including through other approaches, such as, for example, the SelfDetermination Theory, Self-Efficacy, Self-Concept and Ability Self-Perceptions to learn a foreign language, and Causal Attributions Theory. In each approach other variables are taken into account, promising new perspectives on this object of study.

\section{Final Considerations}

The quality of student motivation makes a difference to learning outcomes. The students' orientation to the learning achievement goal, however, is favored by teaching characteristics as they are perceived by the students. Among them, making the class interesting and learning attractive is a motivational strategy particularly suited to teaching certain subjects. Embellishments such as variation, use of music, games, skits, connection to life outside school and the personal interests of their students have demonstrated potential to contribute to engagement in learning.

In the same vein, demonstrating the utility value of learning is a promising way to make it meaningful and of personal valued, leading to a more sustained engagement in the activities. Therefore, right arguments are expected to persuade students to master a certain subject-matter that, in turn, makes it possible to achieve better social relationships, success in life beyond school. In addition, students must see current language learning as a prerequisite for future learning tasks that they look forward. In particular, but not less important, one must acknowledge that teachers' personal 
characteristics are very influential, as they believe and display the importance of their subject, presenting it with enthusiasm, vividness, positive affect with their students, and signs of dedication to his/her job.

\section{References}

Ames, C. (1992). Classrooms: Goals, structures, and student motivation. Journal of Educational Psychology, 84(3), 261-271.

Bzuneck, J. A. (2009a). A motivação do aluno: aspectos introdutórios. In E. Boruchovitch \& J. A. Bzuneck (Orgs.), A motivação do aluno: contribuições da psicologia contemporânea (4ª ed., pp.9-36). Petrópolis: Vozes.

Bzuneck, J. A. (2009b). A motivação do aluno orientado a metas de realização. In E. Boruchovitch \& J. A. Bzuneck (Orgs.), A motivação do aluno: contribuições da psicologia contemporânea (4a ed., pp.57-77). Petrópolis: Vozes.

Bzuneck, J. A. (2010). Como motivar os alunos: sugestões práticas. In E. Boruchovitch, J. A. Bzuneck \& S. E. R. Guimarães (Orgs.), Motivação para aprender: aplicações no contexto educativo (pp.13-42). Petrópolis: Vozes.

Clément, R., Dörnyei, Z., \& Noels, K. A. (1994). Motivation, self-confidence, and group cohesion in the foreign language classroom. Language Learning, 44(3), 417-448.

Cordova, D. I., \& Lepper, M. R. (1996). Intrinsic motivation and the process of learning: Beneficial effects of contextualization, personalization, and choice. Journal of Educational Psychology, 88(4), 715-730.

Dörnyei, Z. (2003). Attitudes, orientations, and motivations in language learning: Advances in theory, research, and applications. Oxford: Blackwell Publishing.

Dowson, M., \& Mclnerney, D. M. (2001). Psychological parameters of students' social and work avoidance goals: A qualitative investigation. Journal of Educational Psychology, 93(1), 35-42.

Durik, A. M., Vida, M., \& Eccles, J. S. (2006). Task values and ability beliefs as predictors of high school literacy choices: A developmental analysis. Journal of Educational Psychology, 98(2), 382-393.

Eccles, J. S., \&Wigfield, A. (2002). Motivational beliefs, values, and goals. Annual Review of Psychology, 53, 109-132.

Gardner, R. C., \& Lambert, W. E. (1959). Motivational variables in second language acquisition. Canadian Journal of Psychology, 13(4), 266-272.

Guimarães, S. E. R. (2009). A organização da escola e da sala de aula como determinante da motivação intrínseca e da meta aprender. In E. Boruchovitch \& J. A. Bzuneck (Orgs.), A motivação do aluno: contribuições da psicologia contemporânea (4a ed., pp.78-95). Petrópolis: Vozes.

Holtgraves, T. (2004). Social desirability and self-reports: Testing models of social desirable responding. Personality and Social Psychology Bulletin, 30(2), 161-172.
Hidi, S. (2001). Interest, reading, and learning: Theoretical and practical considerations. Educational Psychology Review, 13(3), 191-209.

Hidi, S., \& Harackiewicz, J. M. (2000). Motivating the academically unmotivated: A critical issue for the $21^{\text {st }}$ century. Review of Educational Research, 70(2), 151-179.

Kaplan, A., \& Maehr, M. L. (2002). Adolescents' achievement goals: Situating motivation in sociocultural contexts. In F. Pajares \& T. Urdan (Eds.), Academic motivation of adolescents (pp.125-167). Oxford: Information Age Publishing.

Liem, A. D., Lau, S., \& Nie, Y. (2008). The role of self-efficacy, task value, and achievement goals in predicting learning strategies, task disengagement, peer relationship, and achievement outcome. Contemporary Educational Psychology, 33, 486-512.

Noels, K. A., Pelletier, L. G., \& Clément, R. (1999). Perceptions of teachers' communicative style and students' intrinsic and extrinsic motivation. The Modern Language Journal, 83(1), 23-34.

Noels, K. A., Pelletier, L. G., Clément, R., \& Vallerand, R. J. (2000). Why are you learning a second language? Motivational orientations and self-determination theory. Language Learning, 50(1), 57-85.

Oxford, R., \& Shearin, J. (1994). Language learning motivation: Expanding the theoretical framework. The Modern Language Journal, 78(1), 12-28.

Patrick, B. C., Skinner, E. A., \& Connell, J. P. (1993). What motivates children's behavior and emotion? Joint effects of perceived control and autonomy in the academic domain. Journal of Personality and Social Psychology, 65(1), 781-791.

Parker, L. E., \& Lepper, M. R. (1992). Effects of fantasy contexts on children's learning and motivation: Making learning more fun. Journal of Personality and Social Psychology, 62(4), 625-633.

Reeve, J. (2004). Self-determination theory applied to educational settings. In E. L. Deci \& R. M. Ryan (Orgs.), Handbook of self-determination research (pp.183-203). Rochester: University of Rochester Press.

Reeve, J. \& Jang, H. (2006). What teachers say and do to support students' autonomy during a learning activity. Journal of Educational Psychology, 98(1), 209-218.

Roeser, R. W., \& Galloway, M. K. (2002). Studying motivation to learn during early adolescence. In F. Pajares \& T. Urdan (Eds.), Academic motivation of adolescents (pp.331-372). Oxford: Information Age Publishing.

Tsai, Y. M., Kunter, M., Ludtke, O., Trautwein, U., \& Ryan, R. M. (2008). What makes lessons interesting? The role of situational and individual factors in three school subjects. Contemporary Educational Psychology, 100(2), 460-472.

Urdan, T., \& Midgley, C. (2003). Changes in the perceived classroom goal structure and pattern of adaptive learning during early adolescence. Contemporary Educational Psychology, 28(4), 524-551.

Urdan, T., \& Schoenfelder, E. (2006). Classroom effects on student motivation: Goal structures, social relationships 
and competence beliefs. Journal of School Psychology, 44(5), 331-349.

Vallerand, R. J., Fortier, M., \& Guay, F. (1997). Self-determination and persistence in a real-life setting toward a motivational model of high school dropout. Journal of Personality and Social Psychology, 72(5), 1161-1176.

Wigfield, A., \& Eccles, J. S. (2000). Expectancy-value theory of achievement motivation. Contemporary Educational Psychology, 25(1), 68-81.

Williams, M., Burden, R. L., \& Al-Baharna, S. (2002). Making sense of success and failure: The role of the individual in motivation theory. In Z. Dörnyei \& R. Schmidt (Eds.), Motivation and second language acquisition (pp.171-184). Honolulu: University of Hawaii.

Zusho, A., \& Pintrich, P. R. (2001). Motivation in the second decade of life: The role of multiple developmental trajectories. In T. Urdan \& F. Pajares (Eds.), Adolescence and education: General issues in the education of adolescents (pp.163-200). Oxford: Information Age Publishing.

Received on: 11/4/2012

Approved on: 3/5/2012

353 


\section{Appendix}

\section{MEASUREMENT SCALES OF MOTIVATIONAL CONSTRUCTS}

Goal: Learning

1. I like doing Spanish / English exercises even when they give me some work.

5. I strive to do the Spanish / English exercises even if I make some mistakes.

8. In Spanish / English classes, I prefer to solve challenges, even if this is not easy.

11. I like the Spanish / English exercises better when they make me think.

14. I do Spanish / English homework so that I can learn this language.

22. I study Spanish / English hard because I want to practice this language more.

24. I make an effort to learn much more than what is demanded from me in Spanish / English classes.

35. I pay attention to Spanish / English classes.

Goal: Work Avoidance

3. I prefer the easy exercises of Spanish / English.

6. I like it when I can do a Spanish / English exercise without having to make an effort.

13. When I have Spanish / English homework, I do not do it.

17. I think it is not worth studying what will not be on the Spanish / English test.

20. I try to do the Spanish / English exercises, but if they are difficult I give up quickly.

26. I want to do well in Spanish / English tests, but I do not want to study hard.

29. In Spanish / English classes I only do what is required because I think I do not need to do anything extra.

33. I usually copy Spanish / English homework from a colleague.

Perception of Interesting Classroom Teaching

4. I do not like Spanish / English classes because the teacher only gives written exercises.

9. The Spanish / English teacher does not give interesting activities.

16. I love the classes of my school teacher of Spanish / English.

18. I do not feel enthusiastic in Spanish / English classes because the teacher does not take our interests into account.

25. The Spanish / English teacher does not take various materials to diversify the class.

27. I do not like the classes in Spanish / English because they are always the same.

Perception of Motivational Embellishments

30. Spanish / English teacher gives exercises that simulate real-life situations.

32. Spanish / English teacher gives some games about the subject we are studying.

34. Spanish / English teacher arouses our interest using varied tasks.

36. Spanish / English teacher uses music for us to learn to speak and understand new words.

Perception of Uselessness

7. I do not understand the reason to be studying Spanish / English if I do not even think of traveling to any country that speaks that language.

10. I do not know what use there is for studying Spanish / English if I do not know Portuguese well.

15. Classes of Spanish / English are not as important as other subjects.

21. I do not know why I have to waste time studying Spanish / English in school.

28. Studying Spanish / English in school has no meaning in my life.

Perception of Utility

2. Learning Spanish / English is very important today to develop various professions.

12. Spanish / English can be useful for me to continue my studies.

19. Spanish / English is important so that I can travel to other countries.

23. The contents of Spanish / English I am now studying are important for the next grade.

31. I use the Spanish / English I learn in school to listen to music or to play video games. 